\title{
Gastric mucosal status in patients with reflux esophagitis
}

\author{
Riyadh Mohamad Hasan ${ }^{1}$, Batool Mutar Mahdi²
}

1. Department of Surgery, Al-Kindy College of Medicine, University of Baghdad, Iraq

2. Department of Microbiology, Al-Kindy College of Medicine, University of Baghdad, Iraq

\section{RESEARCH}

Please cite this paper as: Hasan RM, Mahdi BM. Gastric mucosal status in patients with reflux esophagitis. AMJ 2017;10(12):1042-1050.

https://doi.org/10.21767/AMJ.2017.3235

\section{Corresponding Author:}

Dr. Batool Mutar Mahdi

Director of HLA Typing Research Unit

Department of Microbiology, Al-kindy College of Medicine University of Baghdad, AL-Nahda Square -Baghdad-Iraq

Email: abas_susan@yahoo.com

\section{ABSTRACT}

\section{Background}

Reflux esophagitis and atrophic gastritis has increased in its frequency in patients with dyspepsia, heartburn and regurgitation.

\section{Aims}

To determine the association of reflux esophagitis, endoscopic gastric mucosal atrophy and histolopathologic atrophy of the gastric mucosa in patients living in Iraq.

\section{Methods}

A group of 130 consecutive patients who were referred to Gastrointestinal Tract Center at Al-Kindy Teaching Hospital (Baghdad-Iraq) from January 2015 to January 2016. The presence or absence of reflux esophagitis, hiatal hernia and atrophic gastritis were determined by endoscopist. Collected gastric biopsy specimens from those patients were examined by for assessment gastric mucosal status and the presence of atrophic gastritis.

\section{Results}

A total of 130 patients were included: 91 men and 39 women, and with mean age of $42.5 \pm 6.7$ years. According to patients profile, endoscope and histopathological examination of gastric biopsies; there was a significant increase $(P=0.0001)$ in number of patients with diffuse antral gastritis (84(70 per cent)) compared to environmental metaplastic atrophic gastritis (36(30 per cent)). There was a significant increase $(P=0.041)$ in the frequency of reflux esophagitis in patients with diffuse antral gastritis (76.19 per cent) than environmental metaplastic atrophic gastritis (55.55 per cent). There was no significant difference $(P=0.479)$ in the assessment of gastric atrophy between endoscopy or histopathology in patients with reflux esophagitis.

\section{Conclusion}

The endoscopic investigation of atrophic gastritis was inversely associated with reflux esophagitis. Endoscopy investigates patients with symptoms of reflux esophagitis because it can confirm or exclude this disease with or without gastric atrophy with certainty.

\section{Key Words}

Reflux, oesophagus, endoscope, stomach, pathology

\section{What this study adds:}

\section{What is known about this subject?}

There is a dyspepsia, abdominal pain, acid regurgitation at least once per month for the past 6 months, heartburn more than three days per week.

\section{What new information is offered in this study?}

The endoscopic investigation of atrophic gastritis was inversely associated with reflux esophagitis and can confirm or exclude this disease with or without gastric atrophy.

3. What are the implications for research, policy, or practice?

Using Endoscopy as a first method to investigate patients because it can confirm or exclude this disease with or without gastric atrophy with certainty. 


\section{Background}

Reflux esophagitis is characterized by the movement of gastric content into the lower section of the oesophagus. It is associated with heartburn, regurgitation; usually twice weekly reflux more than several months that leads to harm the quality of life. ${ }^{1,2}$ The impaired clearance of regurgitated gastric contents in the oesophagus is one of the risk factor of this disease ${ }^{3}$ in association with other factors like hiatal hernia, ${ }^{4}$ obesity, ${ }^{5}$ and consumption of special type of foods and the effect of physical exercise. ${ }^{6}$ One method to diagnose reflux esophagitis is endoscopy that facilitates straight visualizing changes in the gastric mucosa like gastritis and to develop an endoscopic grading system for atrophy with the use of the endoscopic atrophic border. ${ }^{7,8}$ In addition to that, There is an inverse association between reflux esophagitis and atrophic gastritis of the stomach in Japanese, Korean patients and patients in other country. ${ }^{9-11}$ The gastric mucosal status in patients with reflux esophagitis is being assessed by endoscopy since 1969 in Japan. This aids in direct visualizing the changes in the gastric mucosa and grading the atrophy using the atrophic border which is endoscopically recognized by discriminating between the differences in the colour and height of the gastric mucosa. ${ }^{10}$ Atrophic gastritis may affect gastroesophageal reflux. ${ }^{12}$ This may be due to $H$. pylori infection. ${ }^{13}$ In countries where endoscopy services are not existing and laboratory tests about gastric mucosal status using pepsinogens are lacking. The serum pepsinogens level is a helpful biomarker for diagnosing chronic gastritis; furthermore it has moderate sensitivity for atrophic gastritis in dyspeptic patients with low prevalence of Helicobacter pylori. ${ }^{14}$ Children and young people with gastroesophageal reflux disease and positive Helicobacter pylori status had mild gastritis and/or duodenitis. The frequency of gastritis and/or duodenitis does not correlate with the intensity of the reflux esophagitis in them. ${ }^{15}$ So this association between reflux esophagitis and atrophic gastritis is present in patients who lived in different countries. What about the association between these two findings in patients who are living in Iraq? Thus this study tries to determine the association among reflux esophagitis, endoscopic findings and histologic atrophy of the gastric mucosa in patients who are living in Iraq.

\section{Method}

A group of 130 patients diagnosed on endoscopy as having gastritis were included in our study out of 485 patients who were referred to Gastrointestinal Tract Center at Al-Kindy Teaching Hospital (Baghdad-Iraq) due to dyspepsia, upper abdominal discomfort, acid regurgitation of at least once per month for the past 6 months, heartburn more than three days per week according to Montreal Definition and Classification of gastroesophageal reflux disease ${ }^{16}$ from January 2015 to January 2016. The exclusion criteria were patients who had history of gastric surgery, peptic ulcer, gastric cancer, previous $H$. pylori eradication, oesophageal varices and patients who were on medications like antacids, $\mathrm{H} 2$ blockers, proton pump inhibitors and non-steroidal antiinflammatory drugs.

The study protocol was assessed and approved by the Scientific and Ethical Committee of Al-kindy Medical College and Al-Kindy Teaching Hospital.

\section{Evaluation by endoscopy}

The presence or absence of reflux esophagitis (erosive or non-erosive), hiatal hernia and atrophic gastritis were determined by endoscopist according to Los Angeles classification. ${ }^{17}$ Hiatal hernia was defined as a circular extension of the gastric mucosa above the diaphragmatic hiatus more than $2 \mathrm{~cm}$ in axial length. Atrophic gastritis in the gastric body mucosa on endoscopy was diagnosed on the basis of the discoloration of atrophied mucosa with or without blood vessels transparency ${ }^{18}$ and biopsy was taken.

\section{Evaluation by histopathology}

Collected five gastric biopsy specimens from the stomach of those patients using biopsy forceps through the gastroscope from the following locations in the stomach according to Sydney system, one from (A) Lesser curvature of the antrum; one from (B) greater curvature of the antrum; one from (C) lesser curvature of the body; one from (D) greater curvature of the body; and one from $(E)$ incisura angularis ${ }^{19}$ as shown in Figure 1.

Figure 1: Locations of gastric biopsy. (A) Lesser curvature of the antrum; (B) greater curvature of the antrum; (C) lesser curvature of the body; (D) greater curvature of the body; and (E) incisura angularis, according to Sydney system

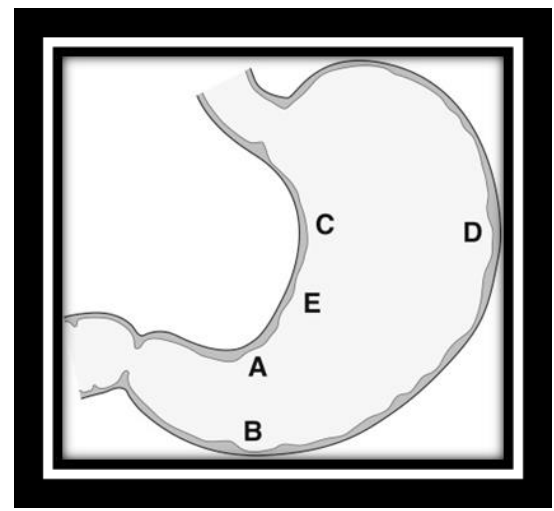


The slides were examined by light microscope for assessment of gastric mucosal status and the presence of atrophic gastritis. The gastritis was either diffuse antral gastritis or environmental metaplastic atrophic gastritis. ${ }^{18}$ Lymphocytic gastritis defined as twenty-five or more intra epithelial lymphocytes per one hundred gastric columnar epithelial cells. $^{20}$ The presence of Helicobacter pylori was assessed by examination with Geimssa stain. Three independent pathologists were blinded to the clinical diagnosis of patients and examined the gastric tissue specimens according to the updated Sydney system. ${ }^{21,22}$

\section{Statistical analysis}

The data is expressed as mean \pm SEM and the Student's t-test was used to assess the statistical significance for age and body mass index according to the state of atrophic gastritis. The differences in gender, alcohol drinking, smoking, reflux esophagitis, and hiatal hernia were assessed using the $\chi^{2}$ test or Fisher's exact test. Odd ratio was also calculated. $p<0.05$ was considered statistically significant. Statistical calculations were performed using SPSS version 10.0 for Windows software (SPSS Inc., Chicago, IL, USA).

\section{Results}

A total of 130 patients with endoscopiacally diagnosed gastritis were included: 91 men and 39 women, and with mean age of $42.5 \pm 6.7$ years. According to patients profile endoscopic examination was used to diagnose the presence or absence of reflux esophagitis (Figure 2). The patients were divided into three groups according the Histopathological examination of gastric biopsies. Group I had diffuse antral gastritis (84) (64.61 per cent) and Group II (36) (27.69 per cent) had environmental metaplastic atrophic gastritis and Group III (10) (7.69 per cent) had normal gastric mucosal biopsy (Table 1 ). There is a significant difference among them $(p=0.0001)$.

The two groups according to histopathology: Group I had diffuse antral gastritis and Group II had environmental metaplastic atrophic gastritis were compared between them regarding different parameters (Table 2 ). There was a significant increase $(P=0.0001)$ in number of patients with diffuse antral gastritis (84/120) (80 per cent) compared to environmental metaplastic atrophic gastritis (36/120) (30 per cent) as shown in Table 2 and Figures 3-7.

Out of 120 patients who had gastritis, only 84 of them had reflux esophagitis either erosive or non-erosive and there was a significant increase $(P=0.041)$ in the frequency of reflux esophagitis in patients with diffuse antral gastritis (group I) (64) (76.19 per cent) than environmental metaplastic atrophic gastritis (group II) (20) (55.55 per cent) (Table 2). Group III who had normal gastric mucosa in endoscope only $2 / 10$ had reflux esophagitis.

There was no significant difference in gender, age, alcohol drinking, body mass index, $\mathrm{H}$ pylori, lymphocytic gastritis or the presence of hiatal hernia between two groups. The patients with diffuse antral gastritis were significantly associated with smoking $(P=0.041)$ (Table 2$)$.

There was no significant difference $(P=0.479)$ in the assessment of gastric atrophy whether by endoscopy or biopsies in patients with reflux esophagitis as shown in Table 3.

Table 3: Frequencies of endoscopic Environmental Metaplastic Atrophic Gastritis as confirmed by gastric biopsies in patients with Reflux esophagitis

\begin{tabular}{|l|l|l|}
\hline $\begin{array}{l}\text { State of gastric mucosa by } \\
\text { endoscope in Reflux } \\
\text { esophagitis patients }\end{array}$ & $\begin{array}{l}\text { Gastric Atrophy } \\
\text { by } \\
\text { histopathology } \\
\text { No. } \%\end{array}$ & P-value \\
\hline $\begin{array}{l}\text { Reflux esophagitis and } \\
\text { atrophy of gastric mucosa by } \\
\text { gastroscope }\end{array}$ & $20 / 3655.55$ & \multirow{2}{*}{0.479} \\
\hline $\begin{array}{l}\text { Reflux esophagitis and } \\
\text { normal of gastric mucosa by } \\
\text { gastroscope }\end{array}$ & $16 / 3644.44$ & \\
\hline Total & 36 & \\
\hline
\end{tabular}

The odd ratio between reflux esophagitis and atrophic gastritis was 11.66 (Table 4).

Table 4: Atrophic gastritis in patients with reflux esophagitis

\begin{tabular}{|l|l|l|l|l|}
\hline & $\begin{array}{l}\text { Patients } \\
\text { with Reflux } \\
\text { esophagitis } \\
\text { No. \% }\end{array}$ & $\begin{array}{l}\text { Patients } \\
\text { with } \\
\text { Atrophic } \\
\text { gastritis } \\
\text { histologically } \\
\text { No. \% }\end{array}$ & $\begin{array}{l}\text { 95\% } \\
\text { confidence } \\
\text { interval }\end{array}$ & $\begin{array}{l}\text { Odd } \\
\text { ratio }\end{array}$ \\
\hline $\begin{array}{l}\text { Patients } \\
\text { who were } \\
\text { examined }\end{array}$ & 8470 & 3630 & $\begin{array}{l}3.134- \\
9.457\end{array}$ & 5.444 \\
\hline
\end{tabular}

The patients with reflux esophagitis were graded according to Los Angeles classification ${ }^{21}$ as shown in Table 5. 
Table 5: Grades of reflux esophagitis's patients according to Los Angeles classification ${ }^{23}$

\begin{tabular}{|l|l|l|}
\hline $\begin{array}{l}\text { Grades of reflux } \\
\text { esophagitis }\end{array}$ & $\begin{array}{l}\text { Number of } \\
\text { patients }\end{array}$ & $\begin{array}{l}\text { Percentage of } \\
\text { patients }\end{array}$ \\
\hline Grade A & 10 & 11.9 \\
\hline Grade B & 42 & 50 \\
\hline Grade C & 32 & 38.09 \\
\hline Grade D & - & - \\
\hline Total & 84 & 99.99 \\
\hline
\end{tabular}

There is a significant differences $(p=0.0001$ and 0.22$)$ in the comparison between endoscopic and histological findings in patients group as demonstrated in Table 6 .

Table 6: The comparison between endoscopic and histological findings in patients group

\begin{tabular}{|l|l|l|l|}
\hline Parameters & $\begin{array}{l}\text { Endoscopic } \\
\text { Findings } \\
\text { No. } \%\end{array}$ & $\begin{array}{l}\text { Histological } \\
\text { findings } \\
\text { No. \% }\end{array}$ & p-value \\
\hline $\begin{array}{l}\text { reflux } \\
\text { esophagitis }\end{array}$ & 8470 & 120100 & 0.0001 \\
\hline $\begin{array}{l}\text { Gastric } \\
\text { Atrophy }\end{array}$ & 2016.66 & 3630 & 0.022 \\
\hline
\end{tabular}

\section{Discussion}

Gastritis was classified into different types and subtypes according to the Sydney classification and OLGA staging system. $^{22,24}$ In this study; diffuse antral gastritis was more common than environmental metaplastic atrophic gastritis. Vakil et al., ${ }^{25}$ reported that antrum gastritis is the most common pattern of gastritis seen in Western populations. This atrophic gastritis had significantly lower frequency of reflux esophagitis as compared with diffuse antral gastritis. This is in agreement with Kim et al., ${ }^{26}$ who reported that reflux esophagitis and symptoms of gastroesophageal reflux disease (heartburn and/or regurgitation) are inversely related with the endoscopic atrophy grade and the histopathologic scoring of atrophy by semi-quantitative evaluation using updated Sydney classification. There were no significant differences in $H$. pylori infections between the two groups, which are in accordance with our results. In addition to that, the scores of intestinal metaplasia and glandular atrophy were significantly lower in the reflux esophagitis symptoms group. This is due to the fact that atrophic gastritis leads to hypochlorhydria (decrease acid secretion), which is inversely related to reflux esophagitis. ${ }^{9}$ The presence of atrophic gastritis is inversely related to reflux esophagitis, but it is not related to Barrett's epithelium of the esophagus as demonstrated in Japanese patients. ${ }^{11,27}$ This may be due to $H$. pylori infection, as Koike et al. $^{28}$ showed that $H$. pylori infection prevented reflux esophagitis by the stimulation of atrophic gastritis and decreased acid secretion. Table 2 showed that there is a difference in the antral gastritis group (normal endoscopy and atrophy on biopsy. Liu et al. ${ }^{29}$ mentioned that the potency of agreement between the findings of endoscopic atrophy of gastric mucosa and the histopathological atrophy was excellent. In both groups of patients with diffuse antral gastritis or environmental metaplastic atrophic gastritis had lymphocytic infiltration of the lamina properia and submucosa indicating a chronic state of gastritis. This state occurs with other disease like Coeliac disease. ${ }^{30}$ American College of Gastroenterology, 2013 which supported with many studies and recommended the PPI trial as the first choice for patients presented with GERD symptoms and the endoscopy choice was reserved only for patients with alarm symptoms. $^{31}$

Endoscopy investigates patients with symptoms of reflux esophagitis because it can confirm or exclude this disease with or without gastric atrophy with certainty and a little time. $^{32}$

Other life style risk factor that affects reflux esophagitis development is tobacco smoking that regarded as an aetiological factor of this disease. ${ }^{33}$ Tobacco can reduce the lower oesophageal sphincter pressure, facilitating reflux of acid. In addition, it reduces the production of saliva that rich in bicarbonate, which is an important buffering media that neutralize acid in the oesophagus. ${ }^{34}$ In our study, 76.19 per cent of patients with diffuse gastritis were positive for smoking and 55.55 per cent had gastric arophy. Other study demonstrated the association between gastritis and reflux disease and detected in 74.4 per cent of cases and in regression analysis, antral gastritis had a significant association with reflux (OR=1.92; 95 per centCl: 1.22- 3.12) while antral and greater curvature gastritis showed $\mathrm{OR}=$ 1.26; 95 per centCl: 0.25-6.40 and $\mathrm{OR}=3.0$; 95 per cent $\mathrm{Cl}$ : $0.63-14.17$, respectively. ${ }^{35}$ In this study, the odd ratio was 5.444 and $\mathrm{Cl}=3.134-9.457$

\section{Conclusion}

In conclusion, the endoscopic examination of atrophic gastritis was inversely associated with reflux esophagitis.

\section{References}

1. Talley NJ, Locke GR 3rd, McNally M, et al. Impact of gastroesophageal reflux on survival in the community. Am J Gastroenterol. 2008;103:12-9. 
2. Wai CT, Yeoh KG, Ho KY, et al. Diagnostic yield of upper endoscopy in Asian patients presenting with dyspepsia. Gastrointest Endosc. 2002;56:548-51.

3. Stanciu C, Bennett JR. Oesophageal acid clearing: one factor in the production of reflux oesophagitis. Gut 1974;15:852-857.

4. Steward RJ, Johnston BT, Boston VE, et al. Role of hiatal hernia in delaying acid clearance. Arch Dis Child. 1993;68:662-664.

5. Barak N, Ehrenpreis ED, Harrison JR, et al. Gastrooesophageal reflux disease in obesity: pathophysiological and therapeutic considerations. Obes Rev. 2002;3:9-15.

6. Nocon M, Labenz J, Willich SN. Lifestyle factors and symptoms of gastro-oesophageal reflux - a populationbased study. Aliment Pharmacol Ther. 2006;23:169-174.

7. Kimura K, Takemoto T. An endoscopic recognition of the atrophic border and its significance in chronic gastritis. Endoscopy. 1969;3:87-97.

8. Kimura K, Satoh K, Ido K, et al. Gastritis in the Japanese stomach. Scand J Gastroenterol Suppl. 1996;214:17-20.

9. Fujiwara $Y$, Higuchi $K$, Shiba $M$, et al. Association between gastroesophageal flap valve, reflux esophagitis, Barrett's epithelium, and atrophic gastritis assessed by endoscopy in Japanese patients. J Gastroentero. 2003;38:533-539.

10. Kim D-H, Kim G-H, Kim J-Y, et al. Endoscopic grading of atrophic gastritis is inversely associated with gastroesophageal reflux and gastropharyngeal reflux. Korean J Intern Med. 2007;22:231-236.

11. Kim GH, Song GA, Kim TO, et al. Endoscopic grading of gastroesophageal flap valve and atrophic gastritis is helpful to predict gastroesophageal reflux. J Gastroenterol Hepatol. 2008;23;208-214.

12. Voutilainen $M$, Sipponen $P$, Mecklin JP, et al. Gastroesophageal reflux disease: prevalence, clinical, endoscopic and histopathological findings in 1,128 consecutive patients referred for endoscopy due to dyspeptic and reflux symptoms. Digestion. 2000;61:613.

13. Satoh K, Kimura K, Taniguchi $Y$, et al. Distribution of inflammation and atrophy in the stomach of Helicobacter pylori-positive and -negative patients with chronic gastritis. Am J Gastroenterol. 1996;91:963-969.

14. Miftahussurur M, Nusi IA, Akil F, et al. Gastric mucosal status in populations with a low prevalence of Helicobacter pylori in Indonesia. PLoS One. 2017;12:e0176203.

15. Nowak A, Brazowski J, Szaflarska-Popławska A. Prevalence of inflammatory changes of gastric and/or duodenal mucosa among children and youth with gastroesophageal reflux. Med Wieku Rozwoj. 2005;9:637-45.

16. Vakil N, van Zanten SV, Kahrilas P, et al. The Montreal definition and classification of gastroesophageal reflux disease: A global evidence-based consensus. Am J Gastroenterol. 2006;101:1900-20.

17. Lundell LR, Dent J, Bennett JR, et al. Endoscopic assessment of oesophagitis: Clinical and functional correlates and further validation of the Los Angeles classification. Gut. 1999;45:172-180

18. Feldman M, Lee EL. Gastritis. In: Sleisenger and Fordtran's Gastrointestinal and Liver Disease. Disease: pathophysiology/diagnosis/management. Ed: Feldman M, Friedman LS, Brandt LJ. $10^{\text {th }}$ edn. Elsevier; 1910;868883.

19. Stolte M, Meining A. The updated Sydney system: Classification and grading of gastritis as the basis of diagnosis and treatment. Can J Gastroenterol. 2001;15:591-598.

20. Haot J, Hamichi L, Wallez L, et al. Lymphocytic gastritis: A newly described entity: a retrospective endoscopic and histological study. Gut. 1988;29:1258-64.

21. Misiewice JJ, Tytgat GNJ, Goodwin CS. The Sydney system: A new classification of gastritis. J Hepathol Gastroenterol. 1991;6:209-222.

22. Genta RM, Dixon MF. The Sydney system revisited: The Houston international gastritis workshop. Am J Gastroenterol. 1995;90:1039-1041.

23. Saraf SS, Udupi GR, Hajare SD. Los Angeles classification of esophagitis using image processing techniques. Int J Comput Appl. 2012;42:45-50.

24. Capelle LG, de Vries AC, Haringsma J, et al. The staging of gastritis with the OLGA system by using intestinal metaplasia as an accurate alternative for atrophic gastritis. Gastrointest Endosc. 2010;71:1150-1158.

25. Vakil N, Talley NJ, Stolte M, et al. Patterns of gastritis and the effect of eradicating Helicobacter pylori on gastro-oesophageal reflux disease in Western patients with non-ulcer dyspepsia. Aliment Pharmacol Ther. 2006;24:55-63.

26. Kim TS, Park DI, Park JH, et al. Association between atrophic gastritis and gastroesophageal reflux symptoms. Hepatogastroenterology. 2013;60:1583-7.

27. Hunt $\mathrm{RH}$. The relationship between the control of $\mathrm{pH}$ and healing and symptom relief in gastro-oesophageal reflux disease. Aliment Pharmacol Ther. 1995;9(Suppl 1):3-7.

28. Koike T, Ohara S, Sekine H, et al. Helicobacter pylori infection prevents erosive reflux oesophagitis by decreasing gastric acid secretion. Gut. 2001;49:330-334.

29. Liu Y, Uemura N, Xiao SD, et al. Agreement between 
endoscopic and histological gastric atrophy scores. J Gastroenterol. 2005;40:123-127.

30. Feeley KM, Heneghan MA, Stevens FM, et al. Lymphocytic gastritis and coeliac disease: evidence of a positive association. J Clin Pathol. 1998;51:207-10.

31. American College of Gastroenterology (ACG). Annual Scientific Meeting and Postgraduate Course. October 11 - 16, 2013; San Diego, California. https://www.medscape.com/viewcollection/32936

32. Armstrong D, Emde C, Inauen W, et al. Diagnostic assessment of gastroesophageal reflux disease: what is possible vs. what is practical? Hepatogastroenterology. 1992;39(Suppl 1):3-13.

33. Yuan L, Tang D, Peng J, et al. Study on lifestyle in patients with gastroesophageal reflux disease. Zhong Nan Da Xue Xue Bao Yi Xue Ban. 2017;28:558-564.

34. Ness-Jensen E, Lagergren J. Tobacco smoking, alcohol consumption and gastro-oesophageal reflux disease. Best Pract Res Clin Gastroenterol. 2017;31:501-508.

35. Nobakht H, Boghratian A, Sohrabi M, et al. Association between pattern of gastritis and gastroesophageal reflux disease in patients with Helicobacter pylori infection. Middle East J Dig Dis. 2016;8:206-211.

\section{ACKNOWLEDGEMENTS}

Our thanks to Gastroscope Unit -AlKindy Teaching Hospital.

\section{PEER REVIEW}

Not commissioned. Externally peer reviewed.

\section{CONFLICTS OF INTEREST}

The authors declare that they have no competing interests.

\section{FUNDING}

None

\section{ETHICS COMMITTEE APPROVAL}

Scientific and Ethical Committee of Al-kindy Medical College and Al-Kindy Teaching Hospital, Approval reference number 4-2017. 
Table 1: Classification of patients with gastritis by endoscope according to histopathological study

\begin{tabular}{|l|l|l|l|l|}
\hline & $\begin{array}{l}\text { Group I diffuse } \\
\text { antral gastritis by } \\
\text { histopathology } \\
\text { No. \% }\end{array}$ & $\begin{array}{l}\text { Group II } \\
\text { environmental } \\
\text { metaplastic } \\
\text { atrophic gastritis by } \\
\text { histopathology } \\
\text { No. \% }\end{array}$ & $\begin{array}{l}\text { Group III normal } \\
\text { gastric mucosal } \\
\text { biopsy by } \\
\text { histopathology } \\
\text { No. \% }\end{array}$ & p- value \\
\hline $\begin{array}{l}\text { Patients with } \\
\text { gastritis by } \\
\text { endoscope } \\
\text { No.=130 }\end{array}$ & (84)(64.61\%) & $(36)(27.69 \%)$ & $(10)(7.69 \%)$ & 0.0001 \\
\hline
\end{tabular}

Table 2: Patients profiles according to histopathologic patterns of chronic gastritis

\begin{tabular}{|c|c|c|c|c|c|}
\hline \multirow{2}{*}{$\begin{array}{l}\text { Patients profile } \\
\text { No. }=120\end{array}$} & \multicolumn{2}{|c|}{$\begin{array}{l}\text { Diffuse Antral Gastritis } \\
\text { (Group I) }\end{array}$} & \multicolumn{2}{|c|}{$\begin{array}{l}\text { Environmental Metaplastic } \\
\text { Atrophic Gastritis (group II) }\end{array}$} & \multirow[t]{2}{*}{ P-value } \\
\hline & No. & $\%$ & No. & $\%$ & \\
\hline $\begin{array}{l}\text { Number of } \\
\text { patients }\end{array}$ & $84 / 120$ & 70 & $36 / 120$ & 30 & 0.0001 \\
\hline $\begin{array}{l}\text { Gender } \\
\text { Men/women }\end{array}$ & $60 / 24$ & $71.42 / 28.57$ & 26-Oct & $72.22 / 27.77$ & 0.887 \\
\hline $\begin{array}{l}\text { Age (years) } \\
\mathrm{X} \pm \text { SEM }\end{array}$ & \multicolumn{2}{|c|}{$38.3 \pm 3.41$} & \multicolumn{2}{|c|}{$45.7 \pm 4.52$} & 0.219 \\
\hline Alcohol drinking & 30 & 35.71 & 8 & 22.22 & 0.24 \\
\hline Smoking & 64 & 76.19 & 20 & 55.55 & 0.041 \\
\hline $\begin{array}{l}\text { Body mass } \\
\text { index } X \pm S E M\end{array}$ & \multicolumn{2}{|c|}{$25.6 \pm 1.7$} & \multicolumn{2}{|c|}{$26.5 \pm 2.6$} & 0.772 \\
\hline $\begin{array}{l}\text { Reflux } \\
\text { esophagitis by } \\
\text { endoscopy }\end{array}$ & 64 & 76.19 & 20 & 55.55 & 0.041 \\
\hline Hiatus hernia & 10 & 11.9 & 7 & 19.44 & 0.423 \\
\hline H pylori & 6 & 7.14 & 7 & 19.44 & 0.095 \\
\hline $\begin{array}{l}\text { lymphocytic } \\
\text { gastritis }\end{array}$ & 80 & 95.23 & 34 & 94.44 & 0.777 \\
\hline
\end{tabular}

Figure 2: Endoscopic examination shows GERD

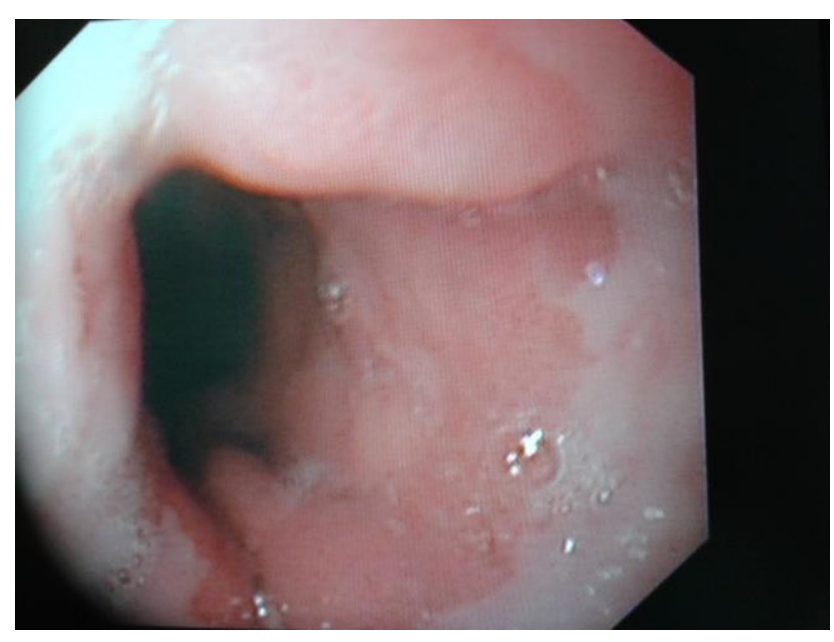


Figure 3: Diffuse antral gastritis with lymphocyte infiltration

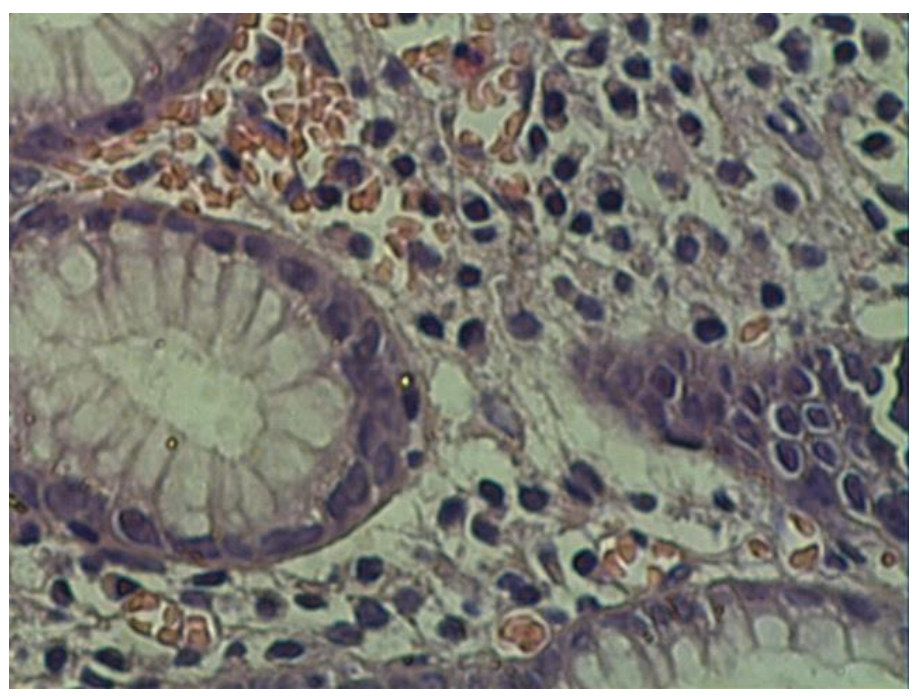

Figure 4: Diffuse antral gastritis with lymphocyte infiltration

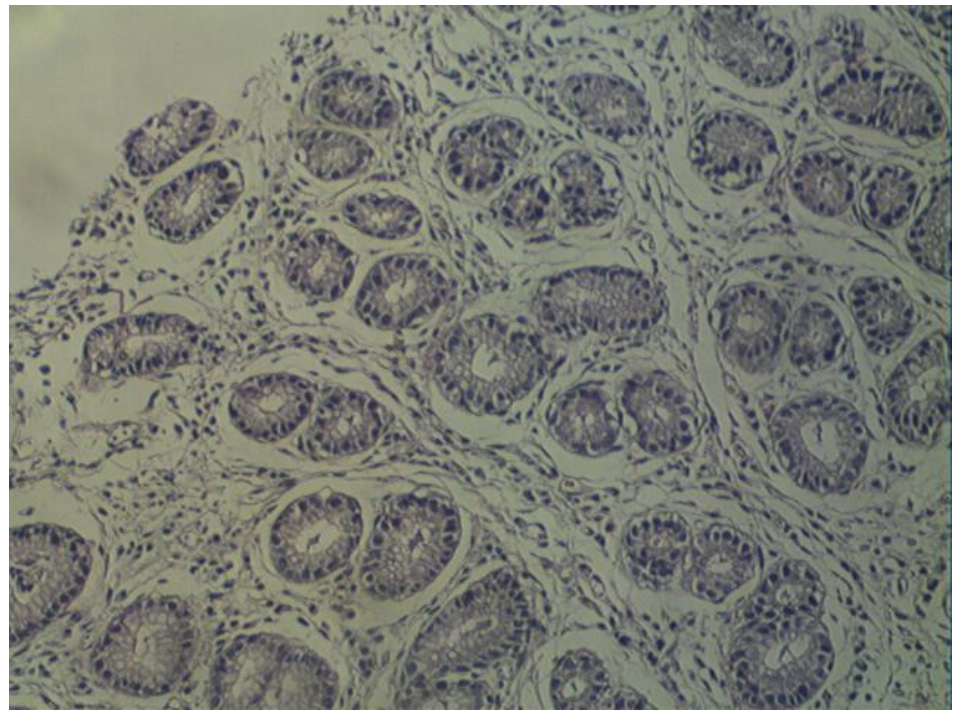

Figure 5: Diffuse antral gastritis with lymphocyte infiltration

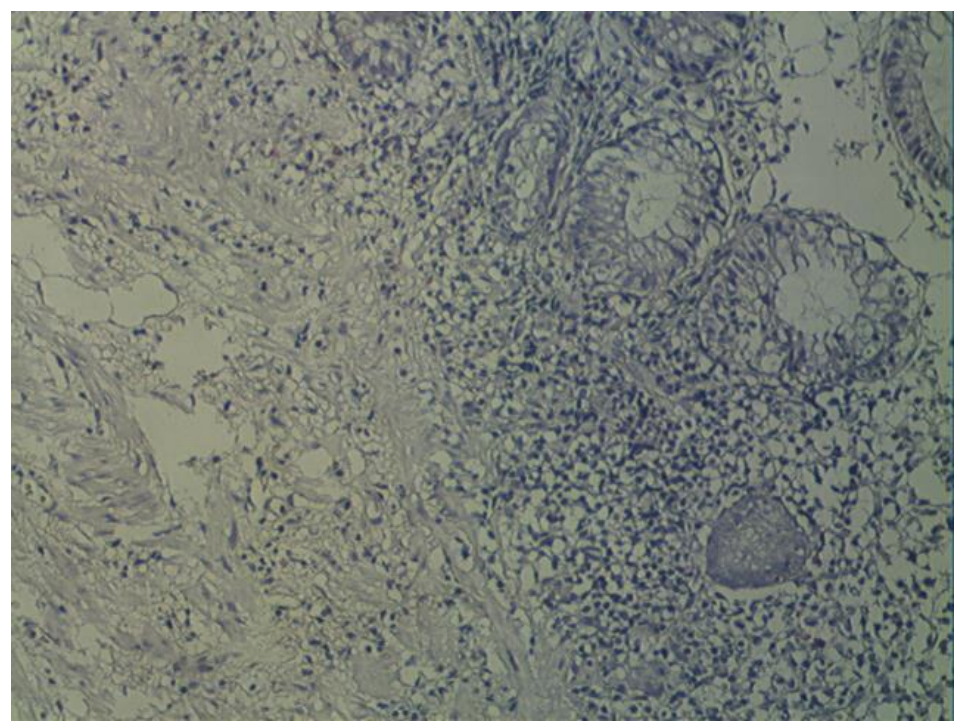


Figure 6: Environmental metaplastic atrophic gastritis

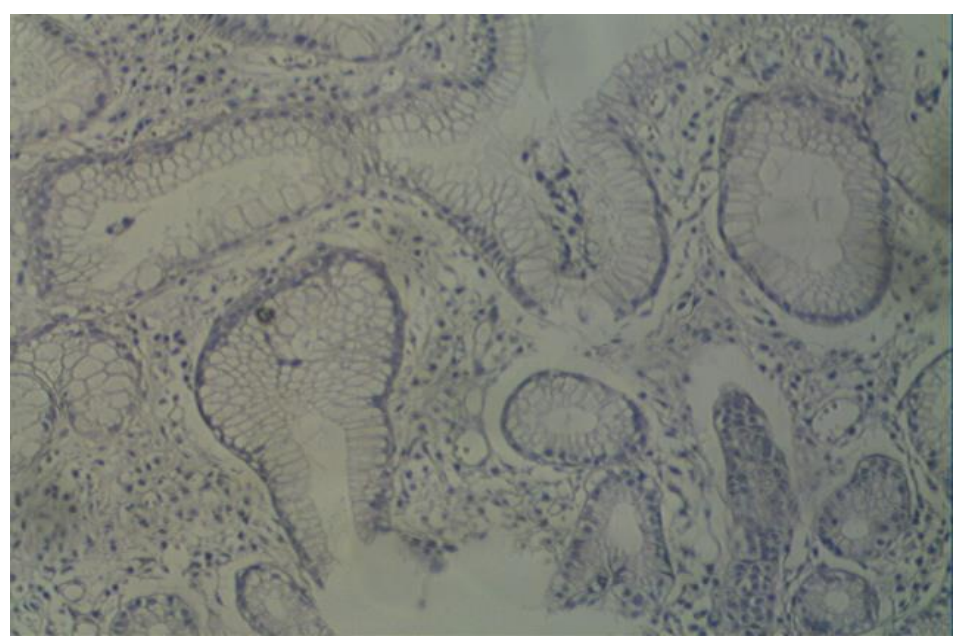

Figure 7: Environmental metaplastic atrophic gastritis

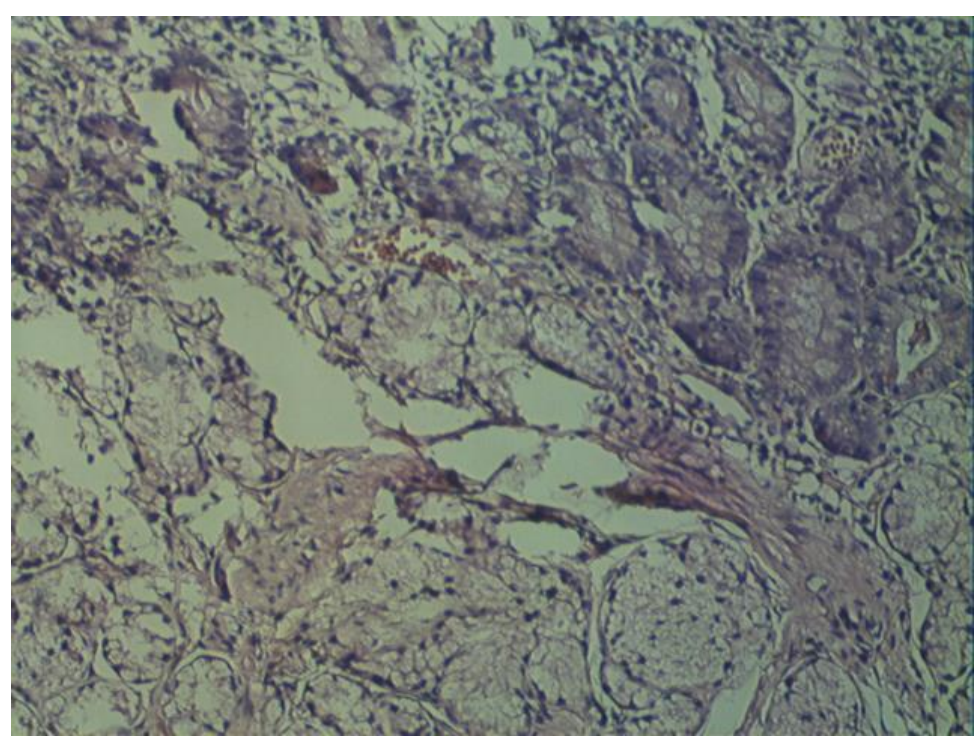

